\title{
Editorial: The Importance of the Astonished Eye
}

\author{
CHARLOTTE CANNING
}

The four articles in this first issue of 2014 could not have, at first glance, less in common. The first piece, 'Zooësis and "Becoming with" in India: The "Figure" of Elephant in Sahyande Makan: The Elephant Project' by Ameet Parameswaran, examines the theatrical adaptation of a 1944 Malayalam poem by the company Theatre Roots and Wings. In 'The Dynamics of Space and Resistance in Muhammad 'Azīz's Tahrir Square: The Revolution of the People and the Genius of the Place', Salwa Rashad Amin discusses the importance of 'Azīz's play in the context of Egypt's recent and historical revolutions. Ketu Katrak takes up the performance of affect and its implication for social justice in "'Stripping Women of Their Wombs": Active Witnessing of Performances of Violence'. Finally, Katia Arfara explores the work of a performance artist in terms of early twentieth-century precedents for European performance art, 'Denaturalizing Time: On Kris Verdonck's Performative Installation End. Theatre Research International readers will find much of value in each article, and they represent the kind of broad international focus our journal endeavours to provide.

But as I read and reread these four works, corresponded with the authors and moved each piece toward publication I realized that they were profoundly linked as diverse examples of the sort of dialectical historicization that playwright, director and theorist Bertolt Brecht calls for in his discussions of the 'not ... but' approach to acting. The title for my editorial is taken from one such discussion where Brecht, in trying to explain how the 'A-effect' might function in everyday life, reports that a friend asked him to look carefully at his watch. The urgency in his friend's voice leads Brecht to realize that he has 'given up seeing the watch itself with an astonished eye; and it is many ways an astonishing piece of machinery'. ${ }^{1}$ The re-recognition of astonishment comes from asking questions, and from following the train of thought the answers reveal. Thus one form of alienation or denaturalization results from seeing the most quotidian things - from objects to people - with an air of astonishment. In acting, this astonishment becomes a way to represent social relations. Brecht terms it 'a discussion (about social conditions) with the audience he $[s i c]$ is addressing. He prompts the spectator to justify or abolish these conditions according to what class he belongs to'. ${ }^{2}$

In order to incite this discussion, in order for a spectator to look with astonishment upon something from her daily life, the actors onstage have to enable her to see how what is onstage was a choice; that is, anything onstage implies those things that were not chosen, that are not onstage. Brecht explains, 'every sentence and every gesture signifies a decision, the character remains under observation and is tested. The technical term for this procedure is "fixing the "not ... but""'. ${ }^{3}$ What Brecht wants us to be able to see onstage is the movement of history, not as a sweep of natural forces beyond anyone's 
control, but as series of selections and discards. Brecht cautions us that it is through the most familiar that we can be astonished: 'we have taken a common, recurrent, universallypracticed operation and tried to draw attention to it by illuminating its peculiarity'. ${ }^{4}$ In other words, the places where we forget we have choice, the ordinary, daily things we do, are the places most ripe for intervention and questioning. Brecht wants us to remember the peculiar in the places where we had elided it.

The four authors in this issue have, in their own ways, given us something we recognize easily - animals, social media, war and time - and demonstrate how the practitioners who took up these subjects brought their audiences to understand them in entirely new ways. Each of the authors also invokes the past, historicizing their subjects without providing histories of them. The understanding that history is always with us allows the authors to tease out the assumptions and attitudes that the performances question, which in turn create the opportunity for audiences to understand the world around them in very different terms than they employed before they saw the production. These articles are about productions that undermine notions of the inevitable.

In 'Zooësis and "Becoming with" in India: The "Figure" of Elephant in Sahyande Makan: The Elephant Project', Ameet Parameswaran critiques Western anthropomorphist discourse that has posited a discrete category of 'human'. He uses the 2008 dramatization of a 1944 Malayalam poem by the Kerala-based theatre company Theatre Roots and Wings to explore 'zooësis'. Zooësis is a term Parameswaran borrows from performance theorist Una Chaudhuri that alludes to the ways in which animals are used to make meaning in cultural representation. Through his discussion of Mikari, the Japanese performer who performs the elephant, Parameswaran engages his readers in complex movement analysis that allows us to rephrase Donna Haraway's question (cited in the article), 'Whom do we touch when we touch a dog?' as 'Whom do we see when we see the human perform the elephant?' But who and what we see is part of a larger history, as Parameswaran demonstrates when he examines the state apparatuses and gendered politics that construct the elephant during the temple festival. He resituates binaries - human/animal or domestic/wild - as categories instantiated by a 'not . . . but' relationship. Brecht notes about that relationship, 'There was not just one possibility but two; both are introduced, then the second one is alienated, then the first as well'. ${ }^{5}$ This article teases out the blurred boundaries between the wild animals that exist almost entirely in captivity and the humans that keep them, and forces its readers to ask questions about our own historically and ideologically constituted identities as humans.

The July 2013 issue of TRI explored theatre and the Arab Spring. Guest editors Hazem Azmy and Marvin Carlson made no claim to have in any way exhausted the complexities of 'where we should look for the "theatrical truth" behind the new Arab realities', as they wrote in their introduction. Indeed, Salwa Rashad Amin gives us another way to do just that by offering her analysis of an influential but unproduced play, Muhammad 'Azīz's Tahrir Square. The play contrasts social networking (through platforms like Facebook) and human networking (face-to-face interactions, especially those in the eponymous square). Amin demonstrates how the play seized on and represented the new definitions of identity, space and resistance made possible by the January 2011 revolution. While current events and the play's dramaturgy are the primary focus of the article, Egypt's 
past revolutions and the dramaturgical/performance responses to those earlier moments are kept in full view. Nothing that happened in 2011 and its aftermath was without precedent. In fact, one way to view the article's argument is 'not 1952 . . but 2011', in that while the choices of 2011 depart significantly from those of 1952, they are made astonishing to us because we know what other choices could have been, and have been, made. Amin asks key questions about how theatre should and can represent revolution and urges us to think about the weight history has, acknowledged or unacknowledged, on our answers.

Ketu Katrak asks the most important question anyone in theatre who strives for social justice can ask: how can what happens onstage move people to action once they have left the theatre? She finds one set of potential answers in the productions of two plays, Lynn Nottage's Ruined, and Navarasa Dance Theater's Encounter, both produced in the US, in 2009 and 2012, respectively. Neither dramatist is a member of the group whose plight she represents, but both are invested in getting audiences to understand how violence against women anywhere indicts us all. Both productions offer us women's bodies that bruise, burn, break, sweat, stink, scream and are silent. In both performances audiences are confronted with the details, and in some cases stagings, of acts of horrific violence. Through post-show talkbacks and other means, Katrak found that audiences, rather than rejecting what they saw and turning away, were eager to discuss, think through and critique both the staging and the real-world conditions. All involved, however, were representing and receiving the work through not just a possible Brechtian lens (Brecht's Mother Courage was the inspiration for Nottage's play), but also a feminist one. As feminist performance theorist Elin Diamond noted in 1988,

If feminist theory sees the body as culturally mapped and gendered, Brechtian historicization insists that this body is not a fixed essence but a site of struggle and change. If feminist theory is concerned with the multiple and complex signs of a woman's life: her color, her age, her desires, her politics - what I want to call her historicity - Brechtian theory gives us a way to put that historicity on view - in the theatre. ${ }^{6}$

Katrak works through the ways in which the historicity, the lives, the struggles, the mapping are performed, as well as how they are received and used.

For Katia Arfara, Kris Verdonck's work engages with theatre and time in ways that open audiences up to new conceptions of time and new ways of understanding what theatre claims to be doing (and whether it is or not). The many installation pieces Arfara examines, with most of her focus on End, formulate a sort of perverse 'not ... but' that would read something like 'not theatre ... but theatre'. At times Verdonck may seem to be creating a separation between theatre and performance to theatre's detriment, but what is actually being worked out is how to re-envision theatre as a site where uncertainty can be more directly experienced and explored. The installation performances question the boundaries between what are usually depicted as discrete dualities - time/space, animate/inanimate, and material/immaterial - so that spectators can never understand their own process through time the same way again. Arfara points to this as a process of historicization. Verdonck draws on both the Italian Futurists and philosopher Henri 
Bergson, who worked in the early twentieth century. The invocation of these almost hundred-year-old works gives Verdonck a way to play with risk and instability, thus questioning not just where we are and how we got here, but also how that influences where we are going.

One can read all four of these articles and have rich and deep experiences without the slightest reference to the effects of historicization or Brecht's 'not ... but' theory. As I read them, however, I was struck by how each author in his or her own way invoked various past moments, not to erase historical difference, but to insist on it. In the insistence on the 'not', the past is not the present; there is still the '... but'. The past is in the present, even if it is not the same thing as the present. As Brecht argued, 'Instead we must leave them [past periods] their distinguishing marks and keep their impermanence before our eyes, so that our own period can be seen to be impermanent too'. ${ }^{7}$ Ameet Parameswaran, Salwa Rashad Amin, Ketu Katrak and Katia Arfara in very different ways astonish us and bring us to re-recognize how theatre can re-envision the most ordinary of things as extraordinary. In doing so, many different kinds of theatre can give us tools for the same task: transforming life as we know it for the better.

NOTES

1 Bertolt Brecht, 'The A-Effect as a Procedure in Everyday Life', in Brecht on Theatre, trans. and ed. John Willett (New York: Hill and Wang, 1964), pp. 141-7, here p. 144.

2 Bertolt Brecht, 'Short Description of a New Technique of Acting Which Produces an Alienation Effect', in Brecht on Theatre, pp. 136-40, here p. 139.

3 Ibid., p. 137.

4 Brecht, 'The A-Effect as a Procedure', p. 145.

5 Ibid., p. 144.

6 Elin Diamond, 'Brechtian Theory/ Feminist Theory: Toward a Gestic Feminist Criticism', TDR 32, 1 (Spring 1988), pp. 82-94, here p. 89.

7 Bertolt Brecht, 'A Short Organum for the Theatre', in Brecht on Theatre, pp. 179-205, here p. 190. 